tionen i bruket av personliga pronomen på en finsk landsbygdsort. - Gustav Bockgård \& Jenny Nilsson (toim.), Interaktionell dialektologi s. 159-197. Uppsala: Institut för språk och folkminnen.

Mielikäinen, Aila - Palander, MarJAT TA 2014: Miten puhutaan murteista? Kansanlingvistinen tutkimus metakielestä. Helsinki: SKS.

Nuolijärvi, Pirkko - Sorjonen, MARJA-LeENA 2005: Miten kuvata muutosta? Puhutun kielen tutkimuksen lähtökohtia murteenseuruuhankkeen pohjalta. Helsinki: Kotimaisten kielten tutkimuskeskus.

Pajunen, Anneli 2001: Argumenttirakenne. Asiaintilojen luokitus ja verbien käyttäytyminen suomen kielessä. Helsinki: SKS.

Paunonen, Heikki 2001: Yksikön 1. persoonan pronominin käyttö Helsingin puhekielessä. - Marianne Blomqvist (toim.), Våra språk i tid och rum. Meddelanden från Institutionen för nordiska språk och nordisk litteratur vid Helsingfors universitet s. 154-168. Helsinfors: Helsingfors universitet.

_ 2006: Lounaismurteiden asema suomen murteiden ryhmityksessä. - Taru Nordlund, Tiina Onikki-Rantajääskö \& Toni Suutari (toim.), Kohtauspaikkana kieli. Näkökumia persoonaan, muutoksiin ja valintoihin s. 249-268. Helsinki: SKS.

Posio, Pekka - Vilkuna, Maria 2013:

Referential dimensions of human impersonals in dialectal European Portuguese and Finnish. - Linguistics 51 s. 177-229. SKS = Suomalaisen Kirjallisuuden Seura. Vilkuna, Maria 1989: Free word order in Finnish. Helsinki: SKS.

VISK = HAKUlinen, AUli - Vilkuna, Maria - Korhonen, Rittta Koivisto, Vesa - Heinonen, Tarja Ristta - Alho, IrJA 2004: Iso suomen kielioppi. Verkkoversio. Helsinki: SKS. http://scripta.kotus.fi/visk (15.3.2017).

\title{
Laulaen sujuvaksi kirjoittajaksi?
}

Jenni Alisaari: Songs and poems in the second language classroom. The hidden potential of singing for developing writing fluency. Turun yliopiston julkaisuja. Annales Universitatis Turkuensis B 426. Turku: Turun yliopisto 2016. Johdanto 64 s. ja kolme artikkelia.

ISBN 978-951-29-6672-1.

Kielitaito jaetaan tavallisimmin neljään osataitoon: ymmärtämiseen, puhumiseen, lukemiseen ja kirjoittamiseen. Nämä taidot kehittyvät osin yhdessä, osin erikseen (ks. esim. Liu \& Costanzo 2013 ja siinä mainitut lähteet). Opetus ja arviointi voi keskittyä yhteen osataitoon tai vaihto- ehtoisesti hyödyttää useita taitoja samanaikaisesti. Jenni Alisaari nostaa väitöskirjassaan esille kysymyksen laulamisen, laulujen kuuntelun ja laulujen sanojen rytmikkään lausumisen yhteydestä kirjoittamisen sujuvoitumiseen. Lähtökohta on kiinnostava, sillä helposti voisi kuvitella laulujen kehittävän ennemminkin puheen sujuvuutta.

\section{Väitöskirjan osa-artikkelit}

Alisaaren kasvatustieteen väitöskirja koostuu kolmesta artikkelista, jotka on kaikki kirjoitettu yhdessä Leena Maria Heikkolan kanssa, sekä artikkeleita yh- 
distävästä tekstistä (64 s.). Ensimmäinen artikkeli "Increasing fluency in L2 writing with singing" on julkaistu Studies in Second Language Learning and Teaching -lehdessä (Alisaari \& Heikkola 2016a). Siinä raportoidaan tutkimusta, jossa eri maista Suomeen kesäkurssille saapuneet suomen kielen yliopisto-opiskelijat on jaettu kolmeen ryhmään. Yhdessä ryhmässä lauletaan suomalaisia lauluja 15 minuutin ajan seitsemällä opetuskerralla, yhteensä 105 minuuttia. Toisessa ryhmässä käytetään saman verran aikaa samojen laulujen kuuntelemiseen, mutta ei lauleta itse. Kolmannessa ryhmässä luetaan rytmikkäästi ääneen samojen laulujen sanoja, mutta niihin ei liitetä melodiaa. Muilta osin ryhmät saivat samanlaista opetusta noin neljän viikon intensiivisen kesäkurssin ajan (yhteensä 80 oppituntia). Osallistujien kielitaidon tasoa arvioitiin sekä kurssille valittaessa että kurssin alussa, ja se vaihteli Eurooppalaisen viitekehyksen (CEFR 2011) taitotasoasteikolla A1:stä B1:een. Tutkijat eivät osallistuneet tähän arviointiin. Kurssin alussa ja lopussa tutkimuksen osallistujat tekivät kirjoittamistehtävän, joka perustui kahteen kuvasarjaan. Kirjoittamisen sujuvuuden mittarina oli tuotettu sanamäärä. Tulokset osoittavat, että laulava ryhmä edistyi eniten kurssin aikana.

Toinen artikkeli "Laulamalla sujuvuutta suomenoppijoiden kirjoittamiseen" on julkaistu Kasvatus-lehdessä (Alisaari \& Heikkola 2016b). Nimen perusteella voisi luulla, että kyse on ensimmäisen artikkelin käännöksestä. Aineisto onkin peräisin samasta interventiosta, mutta siitä on valittu mukaan vain niiden osallistujien suoritukset, joiden kielitaidon yleistaso on Opetushallituksen Kielitaidon tasojen kuvausasteikolla (2004) A2.1. Tämän arvioinnin tekivät tutkijat alkumittauksessa kirjoitetun tekstin perusteella (kaksi itsenäistä arviota, yhtenevyys $95 \%$ ). Näin voitiin sulkea pois lähtötason vaikutus tuloksiin. Erona ensimmäiseen artikkeliin on myös se, että kirjoittamisen sujuvuuden mittareita on enemmän: kirjoitelman kokonaissanamäärän lisäksi on tarkasteltu lausekohtaisia sanamääriä sekä tekstin T-yksiköiden kokonaismäärää ja virheettömien T-yksiköiden määrää. Kansainvälisessä toisen kielen oppimisen tutkimuksessa yleisesti käytetyllä T-yksiköllä tarkoitetaan päälausetta ja sen alisteisia sivulauseita. Niiden määrä siis eroaa virkkeiden määrästä siten, että virkkeen rinnasteiset päälauseet muodostavat kukin oman T-yksikkönsä. T-yksiköiden valinta analyysiyksiköksi osoittautuu kuitenkin tarpeettomaksi, sillä niiden suhteen tutkittavat ryhmät eivät eronneet toisistaan eikä toimintatapojen yhteyttä kirjoittamisen sujuvuuteen voitu osoittaa. Lisäksi raportoidaan kyselystä, jossa opiskelijoilta kysyttiin mielipiteitä laulujen käytön hyödyllisyydestä kielenopetuksessa. Opiskelijoiden vastaukset tukevat havaintoa laulamisen vaikutuksesta kirjoittamisen sujuvoitumiseen.

Kolmas artikkeli "Songs and poems in the language classroom", joka väitöksen aikaan oli vielä arvioitavana, on sittemmin julkaistu Teaching and Teacher Education -lehdessä (Alisaari \& Heikkola 2017). Se esittelee suomi toisena kielenä -opettajille suunnattua verkkokyselyä. Vastaajia oli sähköpostilistojen kautta levitetyssä kyselyssä 94. Opettajilta kysyttiin yhtäältä heidän käsityksiään laulujen ja runojen käytöstä luokkaopetuksessa, toisaalta sitä, kuinka he itse käyttävät lauluja ja runoja opetuksessaan. Näitä kahta ilmiötä, käsityksiä ja toimintaa, koskevia vastauksia vertaillaan toisiinsa. Kyselyyn vastanneet on jaettu ryhmiin toimintaympäristön perusteella. Yhden ryhmän muodostavat koululaitoksen opettajat varhaiskasvatuksesta lukion loppuun. Toinen ryhmä koostuu aikuiskoulutuksen opettajista ja kolmas ulkomailla toimivien Suomi-koulujen opettajista. Muina jakoperusteina käytetään pedagogista kelpoisuutta ja opetuskokemusta. Suurimmalla osalla (72\%) oli 
opettajankoulutus ja useimmilla (62\%) yli viiden vuoden työkokemus. Päätulos on, että opettajien käsitykset ja toiminta eivät ole aina yhteneviä. Opettajaryhmät eivät myöskään eroa merkitsevästi toisistaan.

\section{Koontiteksti}

Yksittäisissä artikkeleissa on yleensä vähänlaisesti tilaa tutkimuksen taustoittamiseen ja kehystämiseen, eikä jo julkaistuja tai julkaistavaksi hyväksyttyjä tekstejä väitösvaiheessa enää voi muokata. Siksi artikkeliväitöskirjan keskeinen osuus ja arvioinnin kohde on aina (edelleen vailla vakiintunutta suomenkielistä nimeä oleva) yhteenveto. Alisaaren koontiteksti esittelee työn taustoja kolmelta alueelta: toisen kielen oppimisen tutkimus, laulujen ja runojen käyttö kielenopetuksessa sekä opettajien käsitysten ja käytänteiden tutkimus. Lisäksi on esitelty työn tavoitteet ja rakenne, tutkimusmenetelmät ja tulokset sekä lopuksi arvioitu työn onnistumista. Valinnat kattavat hyvin tutkimuksen keskeiset näkökulmat.

Kun työ ulottuu kahdelle näkökulmiltaan ja tutkimustraditioiltaan erilaiselle tieteenalalle, kielentutkimukseen ja kasvatustieteeseen, ei tietenkään voi odottaa kovin syvällistä perehtyneisyyttä kaikkiin tutkimussuuntauksiin. Toisen kielen oppimisen yleinen kuvaus (luku 2) on kohtuullisen mittainen ja paikkansapitävä. Se keskittyy relevantteihin teemoihin, mutta uusimmat suuntaukset puuttuvat miltei tyystin. Vanhemmasta tutkimuksesta valitut teemat linkittyvät kyllä tähän tutkimukseen, mutta on vahinko, että 2000-luvun käyttöpohjaiset näkemykset eivät ole mukana, sillä ne tarjoaisivat oivia teoreettisia lähtökohtia saatujen tulosten tarkasteluun. Esimerkiksi toiston ja esiintymisfrekvenssin merkitystä korostavien tutkimusten ottaminen mukaan saatujen tulosten tulkintaan selittäisi ja vahvistaisi niitä - sisältäväthän laulut usein toistuvia elementtejä. Sama koskee konst- ruktiopohjaisia näkemyksiä toisen kielen oppimisesta. Lauluthan tarjoavat oppijalle juuri valmiita konstruktioita, merkityksen ja muodon yhteenliittymiä. Myös valtava muistin ja kielen prosessoinnin tutkimusalue olisi antanut monipuolisempia näkökulmia tulosten tulkintaan, mutta nyt se ohitetaan vain maininnalla. Sama koskee kognitiivista musiikin tutkimusta, jonka alalta olisi myös saattanut löytää syvällisempiä selityksiä saaduille tuloksille - erityisesti sille, miksi laulaminen osoittautui tehokkaammaksi kuin laulujen kuunteleminen tai niiden lukeminen rytmikkäästi ääneen.

Tutkimusaihetta kaikkein läheisimmin koskeva taustaluku laulujen ja runojen käytöstä kielenoppimisen tukena on ajantasaisin ja täydellisin. Se esittelee alueen tutkimusta tasapainoisesti. On tietenkin helpompaa kattaa pienemmän osa-alueen tutkimus kuin laajan ja monipuolisen alueen ja valita sieltä keskeisimmät tutkimukset esiteltäviksi, mutta joka tapauksessa Alisaari osoittaa tässä luvussa hallitsevansa oman alueensa hyvin. Tämä käy ilmi myös aluetta paremmin tuntevan toisen esitarkastajan lausunnosta.

Opettajien käsitysten aiempi tutkimus on mukana hyvin lyhyesti: sitä käsitellään vain reilun sivun verran. Tämä yllättää, sillä alan tutkimus on ollut viime vuosina hyvin aktiivista ja sillä on yhteyksiä moniin muihin toisen kielen oppimisen tutkimuksen alueisiin. Suppeutta selittää ehkä se, että tämä osa työn taustaa liittyy vain kolmanteen artikkeliin (Alisaari \& Heikkola 2017). Kirjoittaja näyttää kuitenkin olevan hyvin perillä käsitysten tutkimisesta, sillä kyselytutkimus on hyvin laadittu ja sen tulosten esittely ja pohdinta mainitussa artikkelissa on asiantuntevaa. Koko työn kannalta olisi kuitenkin ollut suotavaa, että kyselyn teoreettisia lähtökohtia olisi avattu enemmän myös koontitekstissä.

Tutkimuksen tavoitteet on esitetty havainnollisesti taulukkomuodossa (s. 34), 
vaikka varsinaisia koko työtä koskevia tutkimuskysymyksiä ei ole muotoiltu. Artikkeleiden tutkimuskysymykset ovat sisällöltään selkeitä, vaikka hieman epämääräisesti sanoitettu. Menetelmäosuus on tiivis, mutta antaa riittävästi tietoa lukuun ottamatta kahden ensimmäisen artikkelin osallistujajoukon välistä suhdetta, jonka selvittäminen vaatii tiedon hakua useasta työn kohdasta. Tilastolliset menetelmät on valittu ja niitä on käytetty asianmukaisesti. Myös tulosten tulkinta on huolellista. Kaikkiaan valitut menetelmät (interventio luokkahuonetilanteessa, kyselyt ja tulosten analyysiin käytetyt laskentatavat) ovat monesti koeteltuja eivätkä siten erityisen innovatiivisia mutta toimivat kyllä tutkimuksen tavoitteiden saavuttamisessa. Myös artikkeleiden esittely koontitekstissä on sisällöltään riittävä ja sopivan laajuinen.

Päätulokset tukevat ikiaikaista käytäntöä opetella vieraita kieliä luokkahuonetilanteessa laulamalla. Myös laulujen kuunteleminen ja sanojen ääneen lukeminen yhdessä näyttää olevan avuksi, mutta niiden hyödyllisyyttä on ilmeisesti vaikeampi erottaa muista tavoista työskennellä opittavan kielen kanssa. Opettajien käsitykset tukevat tutkimustuloksia, vaikka ne eivät välttämättä näytä muuttuvan toiminnaksi. Opiskelijoiden kokemukset ovat myös myönteisiä, joten tämä tutkimus toivottavasti innostaa opettajia laulamaan opiskelijoidensa kanssa.

\section{Avoimia kysymyksiä}

Tutkimuksen lauluryhmässä käytettiin myös eleitä. Monet oppijat kokevat, että eleet auttavat heitä muistamaan opittavia asioita. Käytännössä ei tietenkään ole merkitystä sillä, hyötyykö oppija melodiasta vai eleistä, ja näiden yhdistäminen antaa eri oppijoille mahdollisuuden heitä eniten hyödyttävään muistiin painamisen tapaan. Tutkimusasetelman kannalta eleet ovat lisämuuttuja, joka hämärtää hieman tulosten tulkintaa.
Tutkimuksen koherenssia häiritsee se, että kyselyyn vastanneiden opettajien joukossa on vain harvoja, jotka opettavat interventiotutkimuksen kohderyhmää. Eri ikä- ja oppijaryhmissä laulujen rooli saattaa olla erilainen, vaikka toki hyvin monenlaiset oppijat innostuvat laulamaan, jos opettaja on asiasta innostunut. Jatkotutkimus voisikin kohdistua siihen, miten laulaminen hyödyttää erilaisia oppijaryhmiä kielenoppimisen eri vaiheissa.

Käytettyihin mittareihin olisi myös voinut suhtautua kriittisemmin. Ne ovat toki tuttuja monista kielenoppimisen tutkimuksista, mutta voi miettiä, onko Tyksikkö todella käyttökelpoinen sujuvuuden mittari. T-yksiköiden käyttö virkkeiden ja lauseiden sijaan pyrkii nostamaan esille alisteisten lauseiden määrän. Ajatuksena on, että alisteiset rakenteet kielivät lingvistisestä kompleksisuudesta. Tämä ei välttämättä pidä paikkaansa aikuisoppijoiden suomen kielen kehityksessä, sillä alisteisuus kognitiivisena ilmiönä on aikuiselle ennestään tuttu ja sen kielelliset toteumat (konjunktiolauseet) eivät suomen kielessä eroa rakenteeltaan päälauseista, relatiivilauseita lukuun ottamatta. T-yksiköiden pituus saattaa kuitenkin kertoa jotain kompleksisuudesta. Virheettömien T-yksiköiden määrä taas liittyy pikemminkin tarkkuuteen kuin sujuvuuteen, ainakin jos lähdetään liikkeelle perinteisestä sujuvuus, tarkkuus ja kompleksisuus -kolmijaosta. Tuotettu sanamäärä sen sijaan toimii melko hyvin kirjoittamisen sujuvuuden mittarina silloin, kun kirjoittamiseen varattu aika ja olosuhteet ovat kaikille samat ja kunkin kirjoittajan suoritusta verrataan hänen aikaisempaan suoritukseensa.

Keskeisin teoreettinen kysymys kognitiivisesti orientoituneen toisen kielen oppimisen tutkimuksen kannalta on laulamisen ja kirjoittamisen välinen yhteys. Kehittääkö laulaminen nimenomaan kirjoittamisen sujuvuutta, vai onko kirjoitussujuvuuden paraneminen seurausta kieli- 
taidon yleisestä kehittymisestä laulamisen avulla? Muita kielenkäytön alueita ei tässä tutkimuksessa arvioitu, joten kysymys jää vastausta vaille. Toisaalta emme myöskään tiedä, kehittikö laulaminen muita kirjoittamisen piirteitä, siis tarkkuutta ja kompleksisuutta (siinä määrin kuin ylipäänsä on mahdollista erottaa sujuvuus, tarkkuus ja kompleksisuus erillisiksi konstrukteiksi). Kysymystä toki pohditaan tässä tutkimuksessa, mutta sen olisi voinut nostaa vahvemmin esiin.

Huomiotta jää se tuloksiin mahdollisesti vaikuttava seikka, että Suomi-kouluissa ja osassa aikuiskoulutusta opetukseen osallistuminen on opiskelijoille vapaaehtoista, kun taas koululaitoksessa ja aikuisten kotoutumiskoulutuksessa osallistuminen on pakollista. Tällä lienee vaikutusta motivaatioon, joka mainitaan tutkimuksessa usein keskeisenä syynä sille, että laulaminen edistää oppimista.

\section{Hyödyllistä tietoa}

Alisaaren väitöskirjan kolme artikkelia ja koontiteksti muodostavat kokonaisuuden huolimatta siitä, että kahden ensimmäisen artikkelin aihe ja asetelma eroavat täysin kolmannen artikkelin sisällöstä. Koontiteksti luo niiden välille yhteyksiä ja kattaa keskeisimmät teoreettiset kysymykset. Tutkimuksen vahvuus on tiukasti suunnitelluissa ja toteutetuissa tutkimusasetelmissa. Interventiosta on rajattu pois kaikki ne ylimääräiset muuttujat, joita on mahdollista säädellä - luokkahuonetutkimuksessahan ei koskaan voi täydellisesti kontrolloida kaikkia osallistujien välisiä eroja. Opettajille suunnattu kysely on huolellisesti suunniteltu ja antaa mahdollisuuden käsitysten ja toiminnan vertaamiseen. Tutkimukset on myös raportoitu hyvin. Edellä esitellyt puutteellisuudet liittyvät lähinnä toisen kielen oppimisen alan teoreettisiin näkökulmiin, jotka ehkä eivät ole yhtä keskeisiä kasvatustieteellisen väitöskirjan näkökulmasta.
Tutkimuksen tulokset vahvistavat tavoitteissa asetettuja odotuksia, mutta ne herättävät myös uusia kysymyksiä. Päätulos on laulamisen hyödyllisyys kirjoittamisen sujvuuden kehitykselle, vaikka ei olekaan kiistatonta, onko vaikutus suora vai välittyykö se kielitaidon yleisen edistymisen kautta (tai miksi niin edes pitäisi olla). Vaikutuksen luonteen tai prosessin selittämistä ei tässä tavoitellakaan. Väitöstutkimus ei tuo täysin uutta tietoa, mutta nostaa esille monia uusia tutkimuskysymyksiä ja antaa näyttöä oppitunneilla laulamisen hyödyistä. Tämä ei suinkaan ole tarpeetonta, sillä tutkimuspohjaisia perusteluja laulamiselle tarvitaan. Etenkin aikuisten kotoutumiskoulutuksessa tapaa oppijoita, joiden aikaisempi koulukokemus on totuttanut heidät siihen, että ainoaa oikeaa opiskelua on harjoitusten tekeminen pulpetissa istuen. Tehokkaammat ja monipuolisemmat opetusmenetelmät hyödyttävät myös heitä, joten opettajat saavat tästä työstä pontta itse hyödyllisiksi arvioimilleen käytänteille.

\section{MAISA MARTIN etunimi.sukunimi@jyu.fi}

\section{Lähteet}

Alisaari, Jenni - Heikkola, Leena MARIA 2016a: Increasing fluency in L2 writing with singing. - Studies in Second Language Learning and Teaching $6 \mathrm{~s}$. 271-292.

_ 2016b: Laulamalla sujuvuutta suomenoppijoiden kirjoittamiseen. - Kasvatus $47 \mathrm{~s}$. 313-326.

- 2017: Songs and poems in the language classroom. Teachers' beliefs and practices. - Teaching and Teacher Education 63 s. 231-242.

$\mathrm{CEFR}=$ Common European framework of reference for learning, teaching, assessment. Council of Europe 2011. http://www. coe.int/t/dg4/education/elp/elp-reg/ cefr_EN.asp. 
Kielitaidon tasojen kuvausasteikko. Helsinki:

Opetushallitus 2004. http://www.oph.fi/ saadokset_ja_ohjeet/opetussuunnitelmien_ja_tutkintojen_perusteet/perusopetus (5.4.2017).

LiU, Jinghua - Costanzo, Kate 2013: The relationship among TOEIC listen- ing, reading, speaking, and writing skills. - Donald Powers (toim.), The research foundation for the TOEIC tests. A compendium of studies 2 s. 1-25. Princeton: Educational Testing Service. http://www. ets.org/Media/Research/pdf/TC2-02.pdf (24.3.2017).

\section{Tajunnanlaajentajia - rekisteri-ilmiöitä ristiin rastiin}

Asif Agha \& Frog (toim.): Registers of communication. Studia Fennica Linguistica 18. Helsinki: Suomalaisen Kirjallisuuden Seura 2015. 339 s. ISBN 978-952-222-673-078.

Kielitieteen ja sen lähialojen keskeisiä tehtäviä on kuvata sitä, miten kielelliset ja muut merkit sekä tilanteiset toiminnot, joissa niitä käytetään, muodostuvat merkityksellisiksi kokonaisuuksiksi. Tällaisia kokonaisuuksia ovat esimerkiksi standardikielet tai murteet, uutiset tai blogitekstit, laulut tai runot, puheet tai arkikeskustelut.

Erilaisille teksteille ja toistuvalle, tunnistettavalle toiminnalle annetaan arkikielessäkin eri nimiä. Analyyttisen kategorian kuvaaminen ja nimeäminen taas on tutkijan työtä. Relevantteja analyyttisiä käsitteitä tässä yhteydessä ovat ainakin kieli ja kielimuoto, genre (tekstilaji), toimintatyyppi - ja rekisteri. Viimeksi mainittu on 200o-luvulla kokenut joillakin lingvisteille relevanteilla aloilla renessanssin pääasiassa Asif Aghan (2007) lingvistis-antropologisen rekisteriytymisen (enregisterment) teorian myötä (ks. esim. Lehtonen 2015: 39-42, 48-50; Madsen, Karrebæk \& Møller toim. 2015; Visakko 2015: 46). Aghan (2007) teoriassa rekisteri on kulttuurisen toiminnan malli, johon sisältyvät semioottiset merkit (myös kielelliset merkit), niiden tulkinta ja sosiaalinen indeksisyys sekä ideologiat (mts. 79-81). Rekisterit syntyvät refleksiivisissä sosiohistoriallisissa rekisteriytymisprosesseissa, joita tutkiakseen on otettava huomioon metapragmatiikka (mts. 55): yksinkertaistaen merkitystä ei ole vain sillä, mitä merkkejä käytetään ja miten, vaan myös sillä, millaisen ideologisen tulkinnan merkit ja niiden käyttö saavat. Tulkinta näkyy metapragmaattisessa toiminnassa, esimerkiksi siinä, millaisen vastaanoton merkit saavat vuorovaikutuksessa.

Helsingin yliopiston folkloristit kokosivat rekisterin käsitteen ympärille kaksi kansainvälistä kollokviota (Register I, 2012 ja Register II, 2013), jotka toivat yhteen folkloristeja, antropologeja, kirjallisuudentutkijoita, filologeja ja lingvistejä. Ensimmäisen kollokvion alaotsikko oli "Intersections of language, context and communication" ja toisen "Emergence, change and obsolescence". Artikkelikokoelma Registers of communication, jota tässä esittelen, on syntynyt näiden kollokvioiden pohjalta.

Kokoelma käsittelee rekisterin käsitteen antia eri aloille. Sekä tutkijat että aiheet edustavat eri maita, maanosia ja kieli- ja kulttuuripiirejä, aiheet jopa eri aikakausia. Moniaalle haarovat polut koituvat teoksessa sekä ansioksi että han- 